\title{
Phosphorylation of MAPK-like proteins in three intertidal macroalgae under stress conditions
}

\author{
María L. Parages, Félix L. Figueroa, Rafael M. Conde-Álvarez, Carlos Jiménez*
}

Department of Ecology, Faculty of Sciences, University of Málaga, 29071 Málaga, Spain

\begin{abstract}
The presence and activation of mitogen-activated protein kinase (MAPK)-like proteins in 3 macroalgae with different morphology and phylogeny (Ulva rigida, Ellisolandia elongata and Cystoseira tamariscifolia) were studied during the experimental workshop of the International Group on Aquatic Productivity. Macroalgae were exposed in the short term (days) to different carbon and nitrogen levels and raised temperature $\left(+4^{\circ} \mathrm{C}\right.$ over ambient conditions) in mesocosms under controlled conditions mimicking current and future ocean acidification. Three MAPK-like proteins of 40, 42 and $44 \mathrm{kDa}$ similar to mammalian p38 kinase (p38), stress-activated protein kinase/c-Jun N-terminal kinase (JNK) and extracellular signal-regulated kinase (ERK) were detected, and their phosphorylation occurred both under low- and high-carbon as well as under low- and high-nitrogen conditions (LC, HC, LN, HN, respectively). Moreover, increased temperature led to differential responses of the MAPKs in these species. In U. rigida, p38 phosphorylation initiated the acclimation to temperature stress in LC, while this role was mainly played by JNK in HC during the first $24 \mathrm{~h}$. In E. elongata, p38 was primarily activated in LCLN and in HC treatment. In C. tamariscifolia, JNK was mainly activated in LN during the first $24 \mathrm{~h}$, while both p38 and JNK were activated in $\mathrm{HC}$, but only after $24 \mathrm{~h}$ at elevated temperature. U. rigida was the only species in which ERK phosphorylation increased at increased temperature. These results suggest that both E. elongata and C. tamariscifolia are close to the upper limit of their temperature range at the temperatures tested in this work, and that Ulvales could have physiological advantages in Mediterranean systems in a scenario of future $\mathrm{CO}_{2}$-enrichment with high nitrogen loads.
\end{abstract}

KEY WORDS: Macroalgae - Stress - Mitogen-activated protein kinase - MAPK - Ocean acidification $\cdot$ Temperature stress $\cdot$ Nutrient availability

\section{INTRODUCTION}

Intertidal algal growth, development, reproduction and productivity are drastically affected by changes in temperature, humidity, salinity, irradiance (both photosynthetically active radiation [PAR] and ultraviolet radiation [UVR]) and nutrient availability (Dring 1982, Lobban \& Harrinson 1994, Davison \& Pearson 1996, Häder \& Figueroa 1997, Gévaert et al. 2003, Gao \& Xu 2010, Karleskint et al. 2010). The expected increase in atmospheric $\mathrm{CO}_{2}$ and the concomitant ocean acidification due to global climate change might increase or negate the effect of these

\footnotetext{
*Corresponding author: carlosj@uma.es
}

stressors, and the response and strategies of adaptation and acclimation to these stressors must be studied according to realistic global change scenarios.

It is widely accepted that increasing atmospheric $\mathrm{CO}_{2}$ emissions are changing the chemistry in the surface layer of the oceans. As more $\mathrm{CO}_{2}$ dissolves in seawater, changes in the speciation of inorganic carbon occur, resulting in more bicarbonate ions $\left(\mathrm{HCO}_{3}^{-}\right)$, more protons $\left(\mathrm{H}^{+}\right)$and fewer carbonate ions $\left(\mathrm{CO}_{3}{ }^{2-}\right)$. The consequences of these changes are a lower $\mathrm{pH}$ and lower saturation state of carbonate ions in the seawater (Hofmann et al. 2013). By the end of this century, the $\mathrm{pH}$ of surface oceans is expected to

() The authors 2014. Open Access under Creative Commons by Attribution Licence. Use, distribution and reproduction are unrestricted. Authors and original publication must be credited. 
drop by 0.3 to 0.5 units (Caldeira \& Wickett 2003, Feely et al. 2004, Orr et al. 2005) due to increasing concentrations of atmospheric $\mathrm{CO}_{2}$ that could reach up to $970 \mathrm{ppm} \mathrm{CO}_{2}$ (Houghton et al. 2001). In addition, both ocean temperature increases due to global warming and increased UVR due to the development of ozone holes may represent a real threat for all sessile marine organisms (Bischof et al. 2006).

In order to face environmental changes, plants have developed a complex metabolic network, through which they detect stress signals and acclimate to the new environmental conditions. Sensing of stress signals and their transduction into appropriate responses is thus crucial for plant survival. These response mechanisms to stress must be rapid and perfectly regulated so that plants can sense the changes. In animal cells and in yeast, these response mechanisms to stress involve the activation of a wellregulated signalling network, in which the central role is played by a specific group of cytoplasmic phosphoproteins called mitogen-activated protein kinases (MAPKs). All eukaryotic cells possess multiple MAPK pathways. External information is transferred to the cell nucleus through a series of phosphorylation/dephosphorylation reactions of the MAPKs that lead to the activation/deactivation of specific groups of genes (Kyriakis \& Avruch 2001). These MAPKs, together with their activators (the socalled MAPK kinases and MAPK kinases kinases) form a cascade. The organization of this functional unit or canonic tri-module is mediated by scaffolding proteins (Pawson \& Scott 1997), which preserve the efficiency and selectivity of MAPK pathways by binding pathway components, thus maintaining pathway integrity and permitting the coordinated activation of MAPK components in response to specific stimuli. To date, 6 MAPK cascades have been proposed in mammalian cells, but only for 3 of these (p38, c-Jun and extracellular signal-regulated kinase, ERK) have all the components been completely identified. When they are phosphorylated, both p38 and stress-activated protein kinase/C-Jun $\mathrm{N}$-terminal kinase (JNK) trigger the response to stress (e.g. UVR, heat, osmolarity, growth factors, hormones), while ERK controls cell proliferation (cell division) and differentiation. All plants possess MAPK homologues, whose activation triggers the acclimation to stress (Ligterink 2000, Mishra et al. 2006, Sinha et al. 2011).

Despite the fact that the study of signal transduction in algae is very recent, different studies with both macro- and microalgae (Jiménez et al. 2004, 2007, García-Gómez et al. 2012, Parages et al. 2012, 2013 , 2014) have clearly shown the presence of p38- like, JNK-like and ERK-like components in algae, as well as their crucial role in acclimation to stress and in cell division (Jiménez et al. 2004, 2007, Parages 2012). A procedure has been developed to detect the presence of these MAPK homologues in several species of Chlorophyta, Rhodophyta and Phaeophyta (Parages et al. 2012), revealing that phosphorylation of p38- and JNK-like MAPKs occurs in Arctic kelps in response to increasing UVR exposure and temperature (Parages et al. 2013) as well as in intertidal macroalgae at the onset of emersion and during periods of the highest irradiation (Parages et al. 2014).

Here we hypothesised that macroalgae phosphorylate and dephosphorylate MAPK-like proteins in response to environmental stress conditions such as acidification, nutrient availability and temperature increase. We investigated the presence and activation of homologues of the p38, JNK and ERK MAPK cascades in 3 different intertidal macroalgal morphotypes, i.e. Ulva rigida, Ellisolandia elongata and Cystoseira tamariscifolia, after exposure to different environmental stressful scenarios (increased ocean acidification, low nitrogen availability and a temperature increase).

\section{MATERIALS AND METHODS}

\section{Algal material, location, sampling and pre-treatment}

On 10 September 2012, we collected macroalgae from 3 different morpho-functional groups ('sheetlike', 'articulate-calcareous' and 'thick-leathery' according to Littler et al. 1983) from the intertidal system of La Araña $\left(36^{\circ} 45^{\prime} \mathrm{N}, 4^{\circ} 18^{\prime} \mathrm{W}\right)$ on the Málaga coast (southern Spain). These macroalgae were Ulva rigida C. Agardh (Chlorophyta), Ellisolandia elongata J. Ellis \& Solander (formerly Corallina elongata J. Ellis et Solander according to Hind \& Saunders 2013) (Rhodophyta), and Cystoseira tamariscifolia (Hudson) Papenfuss (Heterokontophyta), respectively. Whole thalli of the 3 species were harvested and immediately transported in temperature-controlled conditions to the laboratory where epiphytic organisms were carefully removed.

\section{Experimental design}

The experiments were designed to test the interactive effects of the current $\mathrm{pCO}_{2}(380 \mathrm{ppm}$, low carbon: LC) and predicted future concentration for the 
year 2100 (800 ppm, high carbon: HC; Ní Longphuirt et al. 2010) in combination with 2 pulsed nitrate concentrations ( $5 \mu \mathrm{M}$, low nitrogen: $\mathrm{LN}$, and $50 \mu \mathrm{M}$, high nitrogen: HN). The low level of nitrate represents that in coastal waters of Málaga (Ramírez et al. 2005). Thus, $4 \mathrm{C}$ and $\mathrm{N}$ treatments were analysed: LCLN, LCHN, HCLN and HCHN. In addition, the effect of a short-term temperature increase $\left(+4^{\circ} \mathrm{C}\right.$ above ambient conditions) was also tested.

Over $4 \mathrm{~d}$, thalli of the 3 study species $(200 \mathrm{~g}$ fresh weight $[\mathrm{FW}]$ per replicate in the case of $U$. rigida; $400 \mathrm{~g}$ FW for E. elongata and $390 \mathrm{~g} \mathrm{FW}$ for $C$. tamariscifolia) were placed in $\mathrm{C}$ and $\mathrm{N}$ conditions similar to those found in their natural habitat on the coastline of Málaga in the month of September (namely LCLN). Detailed descriptions of the experimental set up of the mesocosms, growth conditions, nutrient concentration and light regime may be found in Stengel et al. (2014, this Theme Section). In brief, the set up consisted of a mesocosm system composed of 4 groups of 9 small open tanks (0.094 $\mathrm{m}^{2}$ surface area, $14 \mathrm{l}$ volume). Each group of 9 tanks (3 replicates for each of the 3 species) was placed inside an open tank of $1000 \mathrm{l}$ connected to a fifth 10001 tank in which 2 water pumps (Aqua Medic OR 2500) were submersed for water circulation. Thermoregulation was achieved by using an Aqua Medic Titan at a constant flow of $0.84 \pm 0.05 \mathrm{l}$ $\mathrm{min}^{-1}$. Temperature was established in each header tank using an AT Control System connected to $150 \mathrm{~W}$ submersible heaters.

Each of the four $1000 \mathrm{l}$ tanks was used for a different combination of C and N (LCLN, LCHN, HCLN, HCHN). Seawater was circulated in each of the 141 tanks by connecting groups of 3 tanks to a 601 header tank in which $\mathrm{pH}, \mathrm{CO}_{2}$ and $\mathrm{N}$ concentration were measured and adjusted. All tanks were placed under natural solar radiation covered with a mesh neutral filter $(32 \%$ of reduction of both PAR and UVR). After the $4 \mathrm{~d}$ acclimation period, the experimental conditions of the different treatments were established for $6 \mathrm{~d}$ before temperature was raised by $4^{\circ} \mathrm{C}\left({ }^{\prime}\right.$ temperature $\left.+4^{\circ} \mathrm{C}^{\prime}\right)$.

\section{Environmental parameters: control and measurement}

A pulse of nitrate was added every morning at 06:00 $\mathrm{h}$ in each tank using $1 \mathrm{M} \mathrm{KNO}_{3}$ to obtain either a final nitrate concentration of $5 \mu \mathrm{M}$ corresponding to the LN condition, or a concentration of $50 \mu \mathrm{M}$ corresponding to the HN condition. The necessary volume of the $1 \mathrm{M} \mathrm{KNO}_{3}$ solution was estimated from the last sampling results of the previous day. In addition, $5 \mu \mathrm{l}$ of $1 \mathrm{mM} \mathrm{K}_{3} \mathrm{PO}_{4}$ solution were also added to every tank every morning to avoid P-limitation.

\section{Fluorometry, electron transport rate and chlorophyll a content}

Maximal quantum yields $\left(F_{\mathrm{v}} / F_{\mathrm{m}}\right)$ were determined according to Schreiber et al. (1986) using pulse amplitude modulated (PAM) fluorometers (PAM-2000, Walz) in the case of $C$. tamariscifolia and E. elongata (one instrument for each species) and a Mini-PAM (Walz) in the case of $U$. rigida. After 15 min of dark acclimation following an initial quasi-dark measurement $\left(\sim 1.5 \mu \mathrm{mol}\right.$ photons $\left.\mathrm{m}^{-2} \mathrm{~s}^{-1}\right)$ to provide estimates of minimum fluorescence $\left(F_{0}\right)$, a saturating flash of $0.8 \mathrm{~s}$ and an intensity of $>4000 \mu \mathrm{mol}$ photons $\mathrm{m}^{-2} \mathrm{~s}^{-1}$ was applied to obtain the maximum fluorescence level from fully reduced Photosystem II (PSII) reaction centres $\left(F_{\mathrm{m}}\right)$, and $F_{\mathrm{v}} / F_{\mathrm{m}}$ was obtained as $F_{\mathrm{v}}=F_{\mathrm{m}}-F_{\mathrm{o}}$.

Effective quantum yields $\left(\Delta F / F_{\mathrm{m}}{ }^{\prime}\right)$ were determined at noon in situ, i.e. from algae growing under solar radiation in the tanks, by using Diving PAM fluorometers (Walz) according to Genty et al. (1989). Three replicates per tank were used. $\Delta F / F_{\mathrm{m}}{ }^{\prime}$ was obtained as $F_{\mathrm{m}}{ }^{\prime}-F_{\mathrm{t}}$, where $F_{\mathrm{m}}{ }^{\prime}$ is the maximum fluorescence yield of the illuminated sample, and $F_{\mathrm{t}}$ is the instantaneous fluorescence of illuminated algae shortly before application of a saturation pulse.

Electron transport rate (ETR, in $\mu \mathrm{mol}$ electrons $\mathrm{m}^{-2}$ $\mathrm{s}^{-1}$ ) through PSII was calculated for each level of actinic light as follows:

$$
\mathrm{ETR}=\Delta F / F_{\mathrm{m}}{ }^{\prime} \times E_{\mathrm{PAR}} \times A \times F_{\mathrm{II}}
$$

where $E_{\mathrm{PAR}}$ is the incident irradiance of PAR $(\lambda=400$ to $700 \mathrm{~nm}$ ). The irradiance was measured in situ by a spherical quantum sensor (US-SQS/L). Absorptance (A) was determined as $A=1-T$, where $T$ is the transmittance as reported by Figueroa et al. (2009). $F_{\text {II }}$ is the fraction of total absorbed quanta in PAR by cellular chlorophyll and its light-harvesting chlorophyll proteins (LHCII) associated with PSII, i.e. 0.5, 0.8 and 0.15 in green, brown and red algae, respectively, according to Grzymski et al. (1997), Figueroa et al. (2003) and G. Johnsen (pers. comm.).

Chlorophyll a ( $\mathrm{chl}$ a) was extracted by grinding the thalli in $\mathrm{MgCO}_{3}$-neutralized acetone. Concentration was calculated according to Ritchie (2006). Data presented in this work correspond to midday measurements, at the moment of highest irradiance, on Day 0 (before the temperature increase), and 24 and $72 \mathrm{~h}$ after the temperature increase. 


\section{Protein extraction, electrophoresis and immunoblot analysis}

Samples for MAPK analysis were taken at noon on Day 0 (prior to the temperature increase) and 24 and $72 \mathrm{~h}$ after the temperature increase. Whole thalli were deep frozen in liquid $\mathrm{N}_{2}$ and stored at $-80^{\circ} \mathrm{C}$ until further processing. Frozen thalli were ground using a Retsch MM400 mixer mill. Proteins were extracted according to the method described by Parages et al. (2012), using a commercial RNA purification kit (RNeasy Plant Mini Kit, Qiagen) to yield clean protein extracts, avoiding interference from polyphenols, acidic polysaccharides and nucleic acids. Furthermore, the phosphorylation state of protein kinases is preserved with this method. Protein extracts were stored at $-80^{\circ} \mathrm{C}$ until further analysis.

Gel electrophoresis, immunoblotting and detection of phosphorylated MAPKs were also performed according to methods described by Parages et al. (2012). Western blots were analysed using Amersham ECL Advance (GE Healthcare) as the chemoluminiscence agent and visualised on a Kodak Gel Logic 1500 Imaging System (Eastman Kodak). All antibodies used detected only the phosphorylated forms (active) of the MAPKs; they were purchased from Cell Signaling Technology and used according to the manufacturer's recommendations. Band intensity analyses were carried out using ImageJ 1.440 software (National Institutes of Health).

\section{Statistical analysis}

Four combinations of $\mathrm{C}$ and $\mathrm{N}$ treatments were considered (LCLN, LCHN, HCLN, HCHN) in the analyses. In addition, both for PAM fluorometry as well as for MAPKs, even though only 2 temperatures were tested (ambient temperature and ambient temperature $+4^{\circ} \mathrm{C}$ ), data at Time 0 (ambient temperature) were compared with data at Time 24 and $72 \mathrm{~h}$ after the temperature increase, and were considered as independent treatments to check acclimation to the new temperature. Results of the PAM fluorometry, ETR and chl a content were analysed by 2-way ANOVAs with 3 independent replicates. Band intensities of the blots were compared by means of 2-way ANOVAs, with 3 to 5 independent replicates for each data point. Values are expressed as means \pm SD. Significant differences as well as interaction of means were compared with the post hoc Holm-Sidak test. For all analyses, p $<0.05$ was considered significant. Statistical analyses were car- ried out using the SigmaPlot 11.0 statistical package (SPSS).

\section{RESULTS}

\section{Photosynthetic responses}

The physiological status of the 3 species of macroalgae under the different conditions of $\mathrm{C}, \mathrm{N}$ and temperature was monitored by means of measuring their maximal quantum yield $\left(F_{\mathrm{v}} / F_{\mathrm{m}}\right)$, ETR and chl a content. Fig. 1a shows that in Ulva rigida, $F_{\mathrm{v}} / F_{\mathrm{m}}$ was initially between 0.5 and 0.7 , being higher in $\mathrm{HC}$ than in LC, and higher in HN than in LN conditions. The $4^{\circ} \mathrm{C}$ temperature increase induced a significant but transitory increase in $F_{\mathrm{v}} / F_{\mathrm{m}}$ in LC treatments and in HCLN after $24 \mathrm{~h}$ (Holm-Sidak, all $\mathrm{p}<0.05$ ), dropping to initial values after $72 \mathrm{~h}$ (Fig. 1a). In addition, $F_{\mathrm{v}} / F_{\mathrm{m}}$ was similar in the LC and HCLN treatments at $24 \mathrm{~h}$ (Table 1). However, in HCHN the response was opposite, i.e. a drop after $24 \mathrm{~h}$ (HolmSidak, all $\mathrm{p}<0.05$ ), followed by an increase to initial values after $72 \mathrm{~h}$. In Ellisolandia elongata, maximal quantum yield was initially low in the mesocosms, ranging from 0.3 to 0.5 (Fig. 1b), with lowest values in LCLN and HCHN. After $24 \mathrm{~h}$ at temperature $+4^{\circ} \mathrm{C}$, $F_{\mathrm{v}} / F_{\mathrm{m}}$ did not significantly differ among treatments (Table 1), reaching values around 0.5 , due to an increase in $F_{\mathrm{v}} / F_{\mathrm{m}}$ values in the LCLN and HCHN treatments, and a decrease in the LCHN and HCLN treatments. However, significant differences in $\mathrm{HCHN}$ treatment appeared between 0 and $24 \mathrm{~h}$ (HolmSidak, $\mathrm{p}<0.05)$. Final $F_{\mathrm{v}} / F_{\mathrm{m}}$ was 0.40 to 0.50 , with no significant differences among treatments (Table 1; Holm-Sidak, all $\mathrm{p}>0.05)$. Finally, in Cystoseira tamariscifolia, the pattern of maximal quantum yield was not affected by the carbon concentration, nitrogen availability or temperature (Fig. 1c), since differences were not statistically different (Table 1 ; HolmSidak, all $\mathrm{p}>0.05)$. In all cases, $F_{\mathrm{v}} / F_{\mathrm{m}}$ values were around 0.7 .

In U. rigida, ETR at noon under solar radiation also varied between treatments (Fig. 2a, Table 1). Initially it was highest in HN treatments, with values above $140 \mu \mathrm{mol}$ electrons $\mathrm{m}^{-2} \mathrm{~s}^{-1}$ in HCHN and $120 \mu \mathrm{mol}$ electrons $\mathrm{m}^{-2} \mathrm{~s}^{-1}$ in LCHN, while in LN, values were around $100 \mu \mathrm{mol}$ electrons $\mathrm{m}^{-2} \mathrm{~s}^{-1}$. In HCHN, the trend was similar to that of $F_{\mathrm{v}} / F_{\mathrm{m}}$ : a drop $24 \mathrm{~h}$ after the increase in temperature, recovering to initial values at $72 \mathrm{~h}$. In HCLN, the trend was also similar to that of $F_{\mathrm{v}} / F_{\mathrm{m}}$, with an initial increase at $24 \mathrm{~h}$ and a drop to initial values after $72 \mathrm{~h}$. No significant differ- 

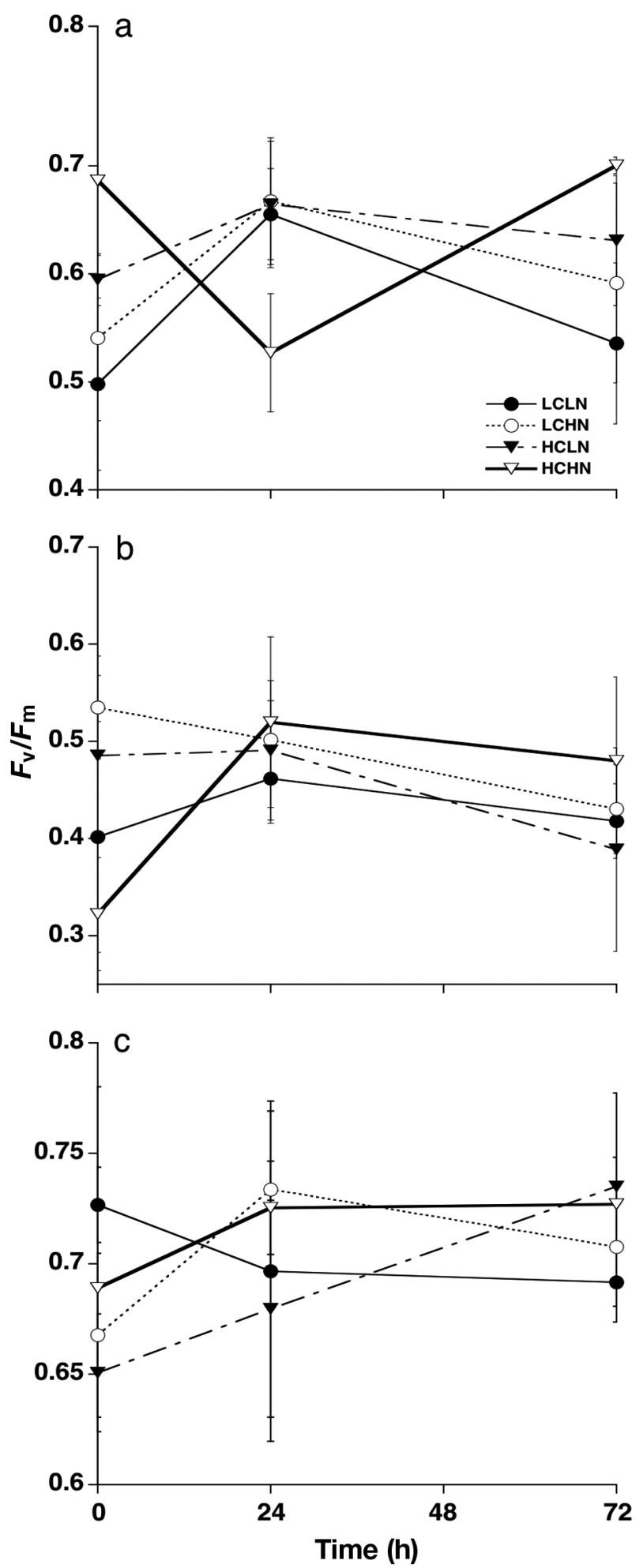

Fig. 1. Maximal quantum yield $\left(F_{\mathrm{v}} / F_{\mathrm{m}}\right)$ of (a) Ulva rigida, (b) Ellisolandia elongata and (c) Cystoseira tamariscifolia under different conditions of carbon, nitrogen and temperature increase analysed by pulse amplitude modulated (PAM) fluorometry. Data show means \pm SD. LCLN: low carbon, low nitrogen; LCHN: low carbon, high nitrogen; HCLN: high carbon, low nitrogen; HCHN: high carbon, high nitrogen
Table 1. Two-way ANOVA results for the effect of temperature and nutrient levels on maximal quantum yield $\left(F_{\mathrm{v}} / F_{\mathrm{m}}\right)$, electron transport rate (ETR) and chlorophyll a (chl a) in Ulva rigida, Ellisolandia elongata and Cystoseira tamariscifolia. We compared data at Time 0 (= ambient temperature) with data at 24 and $72 \mathrm{~h}$ after a temperature increase of $4^{\circ} \mathrm{C}$, and considered these as independent treatments to check acclimation to the new temperature. Algae were exposed to 4 different carbon and nitrogen treatments: low $\mathrm{C}$, low $\mathrm{N}_{\text {; }}$ low $\mathrm{C}$, high $\mathrm{N}_{\text {; }}$ high $\mathrm{C}$, low $\mathrm{N}$; high $\mathrm{C}$, high $\mathrm{N} .{ }^{*} \mathrm{p}<0.05$

\begin{tabular}{|lccc|}
\hline Factor & df & $F$ & $\mathrm{p}$ \\
\hline Ulva rigida & & & \\
Maximal quantum yield & & & \\
Temperature & 2,24 & 2.032 & 0.154 \\
C and N treatments & 3,24 & 2.731 & 0.067 \\
Temperature $\times$ Treatments & 6,24 & 4.960 & $0.002^{*}$ \\
ETR & & & \\
Temperature & 2,24 & 1.876 & 0.175 \\
C and N treatments & 3,24 & 18.546 & $<0.001^{*}$ \\
Temperature $\times$ Treatments & 6,24 & 1.784 & 0.145 \\
Chl a & & & \\
Temperature & 2,24 & 17.228 & $<0.001^{*}$ \\
C and N treatments & 3,24 & 16.521 & $<0.001^{*}$ \\
Temperature $\times$ Treatments & 6,24 & 1.230 & 0.326 \\
Ellisolandia elongata & & & \\
Maximal quantum yield & & & \\
Temperature & 2,24 & 2.699 & 0.088 \\
C and N treatments & 3,24 & 1.172 & 0.342 \\
Temperature $\times$ Treatments & 6,24 & 2.279 & 0.071 \\
ETR & & & \\
Temperature & 2,24 & 1.451 & 0.254 \\
C and N treatments & 3,24 & 2.509 & 0.083 \\
Temperature $\times$ Treatments & 6,24 & 0.868 & 0.532 \\
Chl a & & & \\
Temperature & 2,24 & 7.991 & $0.002^{*}$ \\
C and N treatments & 3,24 & 5.038 & $0.008^{*}$ \\
Temperature $\times$ Treatments & 6,24 & 1.728 & 0.158 \\
Cystoseira tamariscifolia & & & \\
Maximal quantum yield & & & \\
Temperature & 2,24 & 1.587 & 0.226 \\
C and N treatments & 3,24 & 0.454 & 0.717 \\
Temperature $\times$ Treatments & 6,24 & 1.271 & 0.309 \\
ETR & & & \\
Temperature & 2,24 & 18.750 & $<0.001^{*}$ \\
C and N treatments & 3,24 & 1.252 & 0.313 \\
Temperature $\times$ Treatments & 6,24 & 1.705 & 0.163 \\
Chl a & & & \\
Temperature & 2,24 & 2.398 & 0.112 \\
C and N treatments & 3,24 & 2.145 & 0.121 \\
Temperature $\times$ Treatments & 6,24 & 1.226 & 0.328 \\
\hline & & & \\
\hline
\end{tabular}

ences appeared in LCHN during the experiments (Holm-Sidak, all $p$ > 0.05). In general, slight or no differences appeared in ETR values after $72 \mathrm{~h}$ at temperature $+4^{\circ} \mathrm{C}$ in $U$. rigida. In the case of E. elongata (Fig. 2b), ETR values at noon were in the range 86 to $89 \mu \mathrm{mol}$ electrons $\mathrm{m}^{-2} \mathrm{~s}^{-1}$ in all treatments at Time 0 ( $\mathrm{T}=0$, ambient temperature), showing a small but 
steady decrease to values around $80 \mu \mathrm{mol}$ electrons $\mathrm{m}^{-2} \mathrm{~s}^{-1}$ after $72 \mathrm{~h}$ at temperature $+4^{\circ} \mathrm{C}$ in $\mathrm{LC}$ and in HCHN (no significant differences between treatments were found; Table $1 ;$ Holm-Sidak, all $p>0.05$ ). However, in HCLN, a transient increase to nearly $100 \mu \mathrm{mol}$ electrons $\mathrm{m}^{-2} \mathrm{~s}^{-1}$ was detected after $24 \mathrm{~h}$, after which values decreased to initial ones at $72 \mathrm{~h}$. In C. tamariscifolia, ETR values at noon decreased slightly (but significantly; Holm-Sidak, all $\mathrm{p}<0.05$ ) in LN treatments after $72 \mathrm{~h}$ (Fig. 2c, Table 1), dropping from values around $375 \mu \mathrm{mol}$ electrons $\mathrm{m}^{-2} \mathrm{~s}^{-1}$ to values around $350 \mu \mathrm{mol}$ electrons $\mathrm{m}^{-2} \mathrm{~s}^{-1}$. It is worth noting that ETR was much higher in C. tamariscifolia than in the other 2 species, with E. elongata having the lowest ETR.

Chl a content in U. rigida (Fig. 3a) was always higher in LC than in $\mathrm{HC}$, and in $\mathrm{HN}$ than in LN, both before and after the temperature increase (Table 1). There was a transient increase in chl a content in HN $(24 \mathrm{~h})$, followed by a drop to initial values after $72 \mathrm{~h}$ (Holm-Sidak, all p < 0.05). In E. elongata, the chl a content (Fig. 3b) was also higher in LC than in $\mathrm{HC}$ after $72 \mathrm{~h}$. It did not vary after the temperature increase in LC treatments; however, in HC treatments it showed a slight decrease after $72 \mathrm{~h}$ at increased temperature (Table 1; Holm-Sidak, all $\mathrm{p}<$ 0.05). Finally, the chl a concentration in C. tamariscifolia (Fig. 3c) was not affected by the transient increase in temperature, as none of the differences were significant (Table 1; Holm-Sidak, all p > 0.05).

\section{MAPK-like proteins}

Three phosphorylated MAPK-like proteins were detected in all species. In $U$. rigida, a phosphorylated $42 \mathrm{kDa}$ JNK-like protein (Fig. 4a) was detected before the change in temperature (Time 0), with the highest level of this phosphorylation in LC conditions (3 times higher than in HC). However, 24 and $72 \mathrm{~h}$ after the increase in temperature, all growth conditions showed similar phosphorylation. The behaviour was different at $\mathrm{LC}$ and $\mathrm{HC}_{i}$ in the first case, a continuous decrease in the degree of phosphorylation occurred after the increase in temperature, while a transient increase at $24 \mathrm{~h}$ was detected in $\mathrm{HC}$, followed by a decrease to the initial phosphorylation state after $72 \mathrm{~h}$ at temperature $+4^{\circ} \mathrm{C}$. This transient increase in $\mathrm{HC}$ together with the continuous decrease in LC led to a similar degree of phosphorylation in the 4 treatments at the end of the experiments. The level of $\mathrm{N}$ induced significant difference in the phosphorylation of this JNK in U. rigida after $72 \mathrm{~h}$
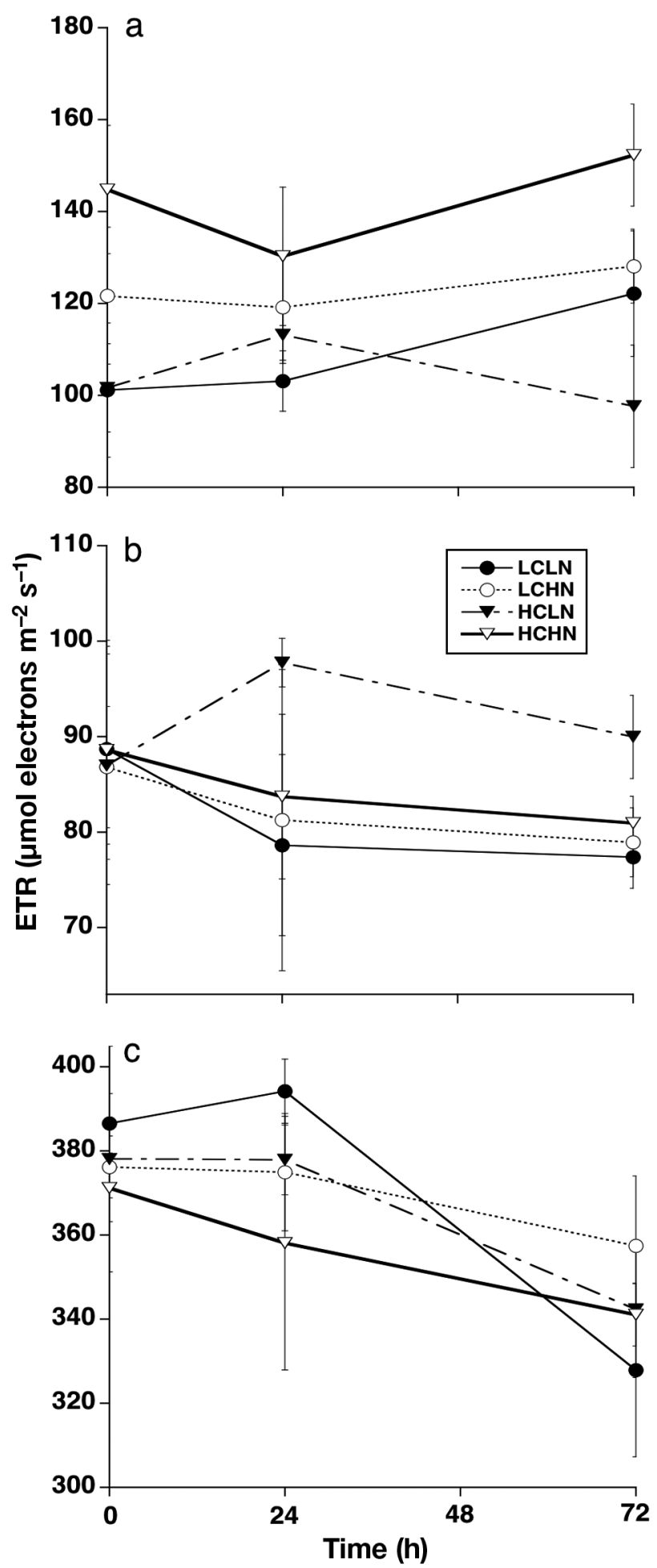

Fig. 2. Electron transport rate (ETR) through Photosystem II expressed as $\mu \mathrm{mol}$ electrons $\mathrm{m}^{-2} \mathrm{~s}^{-1}$ determined in situ (algae growing in the tanks under solar radiation) in (a) Ulva rigida, (b) Ellisolandia elongata and (c) Cystoseira tamariscifolia under different conditions of carbon, nitrogen and temperature increase. Data show means \pm SD. LCLN: low carbon, low nitrogen; LCHN: low carbon, high nitrogen; HCLN: high carbon, low nitrogen; $\mathrm{HCHN}$ : high carbon, high nitrogen 

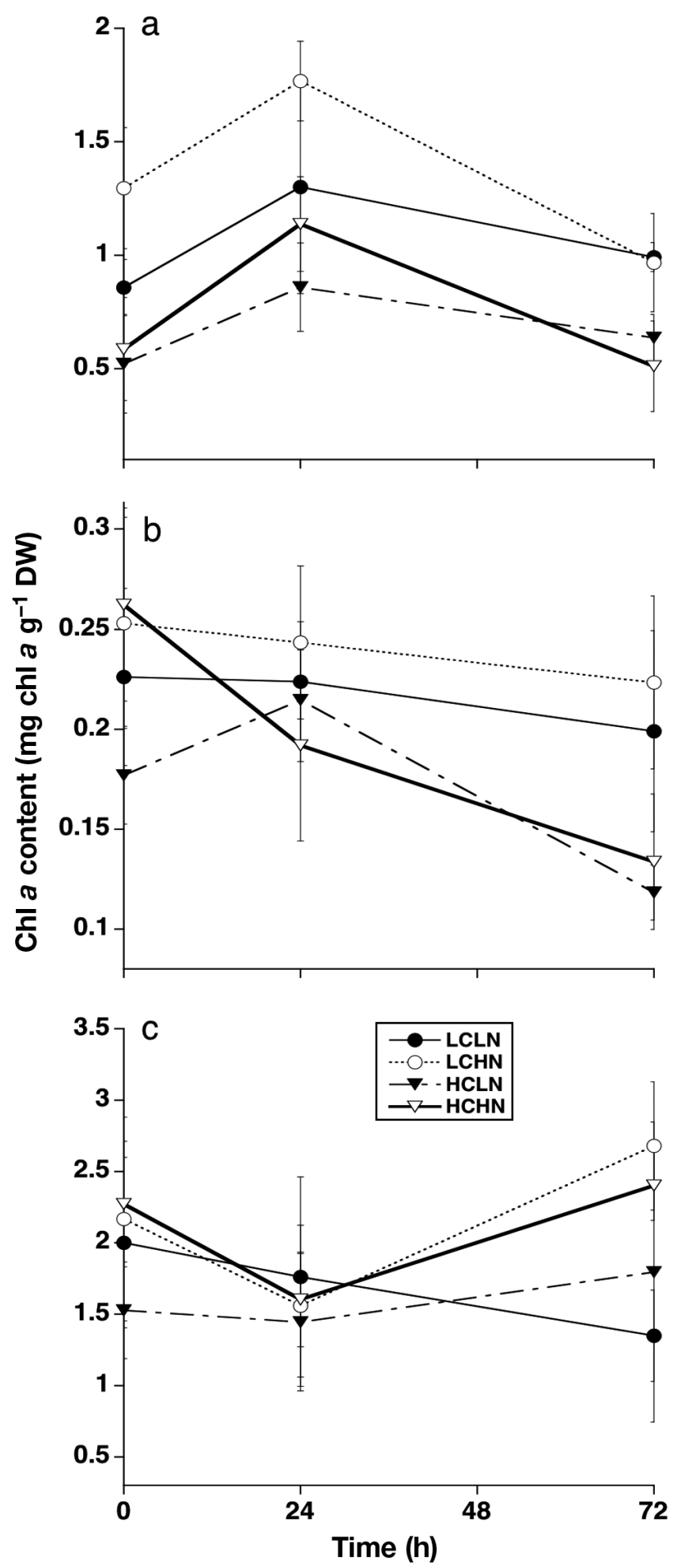

Fig. 3. Chlorophyll a (chl a) content expressed as $\mathrm{mg} \mathrm{g}^{-1}$ dry weight (DW) in (a) Ulva rigida, (b) Ellisolandia elongata and (c) Cystoseira tamariscifolia under different conditions of carbon, nitrogen and temperature increase. Data show means \pm SD. LCLN: low carbon, low nitrogen; LCHN: low carbon, high nitrogen; HCLN: high carbon, low nitrogen; HCHN: high carbon, high nitrogen

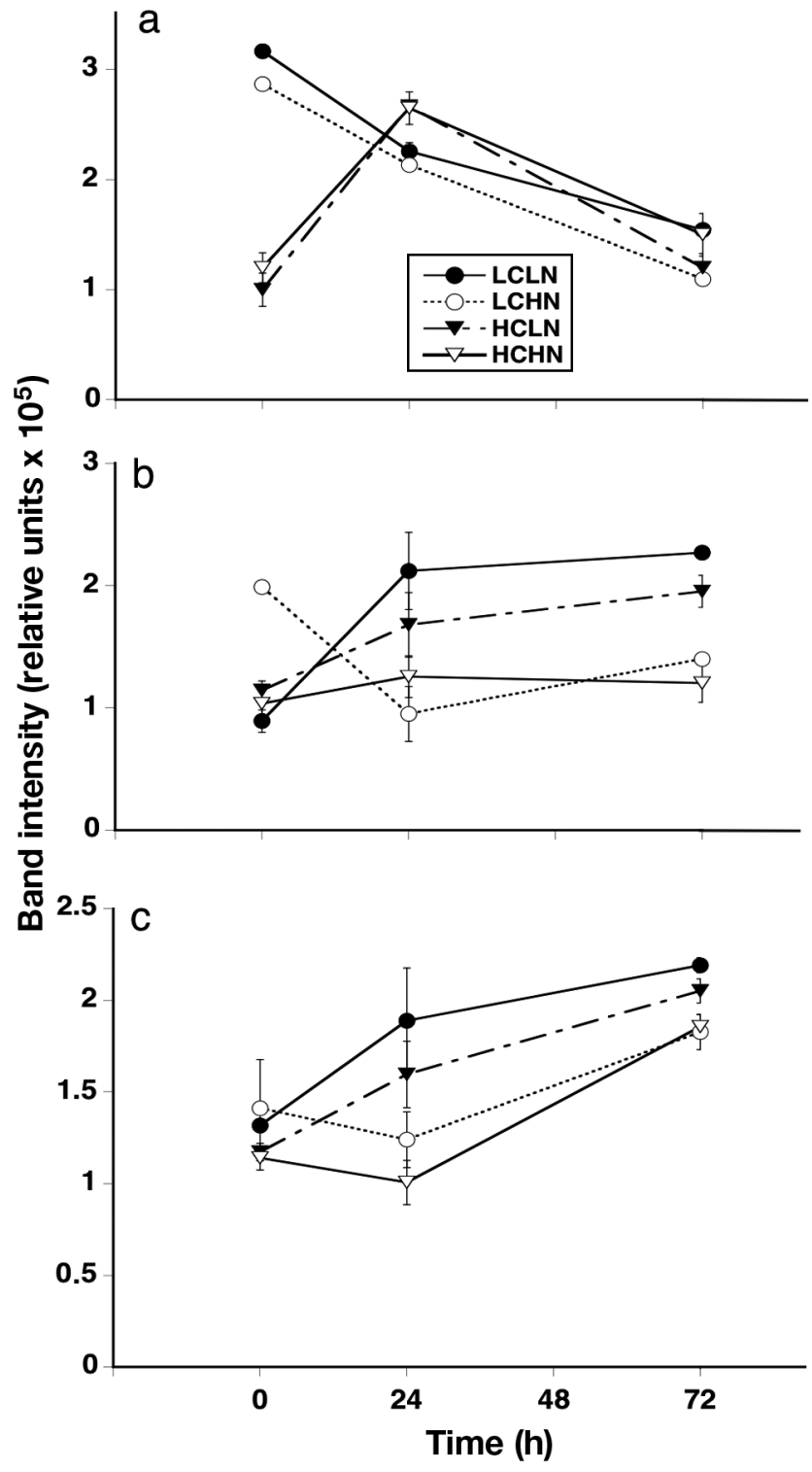

Fig. 4. Expression levels of the phosphorylated JNK-like proteins in (a) Ulva rigida, (b) Ellisolandia elongata and (c) Cystoseira tamariscifolia exposed to different carbon and nitrogen treatments (LCLN: low $\mathrm{C}$, low $\mathrm{N}_{\text {; }} \mathrm{LCHN}$ : low $\mathrm{C}$, high $\mathrm{N}_{i}$ HCLN: high $\mathrm{C}$, low $\mathrm{N}_{\text {; }} \mathrm{HCHN}$ : high $\mathrm{C}$, high $\mathrm{N}$ ). Algae were sampled at Time 0 (start of the experiment), and 24 and $72 \mathrm{~h}$ after a $4^{\circ} \mathrm{C}$ temperature increase. Data are mean $( \pm \mathrm{SE} ; \mathrm{n}=3)$ band intensity measured on Western blots

(Holm-Sidak, all $\mathrm{p}<0.05$ ). Both temperature and treatment, as well as their interaction, induced significant differences in the level of phosphorylated JNK (Table 2). Similarly, a JNK-like protein of $42 \mathrm{kDa}$ was detected in E. elongata, showing clear phosphorylation at Time 0 , mainly in the LCHN treatment (Fig. 4b). The level of phosphorylation in this treatment dropped drastically after $24 \mathrm{~h}$ at tempera- 
Table 2. Two-way ANOVA results for the effect of temperature and nutrient conditions on the levels (based on band intensity in Western blots) of phosphorylated MAPK-like proteins (Ph-JNK, Ph-p38 and Ph-ERK) in Ulva rigida, Ellisolandia elongata and Cystoseira tamariscifolia. We compared data at Time 0 (=ambient temperature) with data at 24 and $72 \mathrm{~h}$ after a temperature increase of $4^{\circ} \mathrm{C}$, and considered these as independent treatments to check acclimation to the new temperature. Algae were exposed to 4 different carbon and nitrogen treatments: low $\mathrm{C}$, low $\mathrm{N}_{\text {; low }} \mathrm{C}$, high $\mathrm{N}_{\text {; }}$ high C, low $\mathrm{N}_{\text {; }}$ high $\mathrm{C}$, high $\mathrm{N}$ ). ${ }^{*} \mathrm{p}<0.05$

\begin{tabular}{|c|c|c|c|}
\hline Factor & df & $F$ & $\mathrm{p}$ \\
\hline \multicolumn{4}{|l|}{ Ulva rigida } \\
\hline \multicolumn{4}{|l|}{ Ph-JNK } \\
\hline Temperature & 2,12 & 265.337 & $<0.001^{*}$ \\
\hline $\mathrm{C}$ and $\mathrm{N}$ treatments & 3,12 & 114.686 & $<0.001^{*}$ \\
\hline Temperature $\times$ Treatments & 6,12 & 165.932 & $<0.001^{*}$ \\
\hline \multicolumn{4}{|l|}{ Ph-p38 } \\
\hline Temperature & 2,12 & 339.931 & $<0.001^{*}$ \\
\hline $\mathrm{C}$ and $\mathrm{N}$ treatments & 3,12 & 44.661 & $<0.001^{*}$ \\
\hline Temperature $\times$ Treatments & 6,12 & 13.536 & $<0.001^{*}$ \\
\hline \multicolumn{4}{|l|}{ Ph-ERK } \\
\hline Temperature & 2,12 & 146.330 & $<0.001^{*}$ \\
\hline $\mathrm{C}$ and $\mathrm{N}$ treatments & 3,12 & 96.153 & $<0.001^{*}$ \\
\hline Temperature $\times$ Treatments & 6,12 & 40.458 & $<0.001^{*}$ \\
\hline \multicolumn{4}{|l|}{ Ellisolandia elongata } \\
\hline \multicolumn{4}{|l|}{ Ph-JNK } \\
\hline Temperature & 2,12 & 14.731 & $<0.001^{*}$ \\
\hline $\mathrm{C}$ and $\mathrm{N}$ treatments & 3,12 & 32.194 & $<0.001^{*}$ \\
\hline Temperature $\times$ Treatments & 6,12 & 29.214 & $<0.001^{*}$ \\
\hline \multicolumn{4}{|l|}{ Ph-p38 } \\
\hline Temperature & 2,12 & 151.667 & $<0.001^{*}$ \\
\hline $\mathrm{C}$ and $\mathrm{N}$ treatments & 3,12 & 25.968 & $<0.001^{*}$ \\
\hline Temperature $\times$ Treatments & 6,12 & 33.678 & $<0.001^{*}$ \\
\hline \multicolumn{4}{|l|}{ Ph-ERK } \\
\hline Temperature & 2,12 & 116.559 & $<0.001^{*}$ \\
\hline $\mathrm{C}$ and $\mathrm{N}$ treatments & 3,12 & 127.744 & $<0.001^{*}$ \\
\hline Temperature $\times$ Treatments & 6,12 & 118.957 & $<0.001^{*}$ \\
\hline \multicolumn{4}{|l|}{ Cystoseira tamariscifolia } \\
\hline \multicolumn{4}{|l|}{ Ph-JNK } \\
\hline Temperature & 2,12 & 138.683 & $<0.001^{*}$ \\
\hline $\mathrm{C}$ and $\mathrm{N}$ treatments & 3,12 & 28.267 & $<0.001^{*}$ \\
\hline Temperature $\times$ Treatments & 6,12 & 10.027 & $<0.001^{*}$ \\
\hline \multicolumn{4}{|l|}{ Ph-p38 } \\
\hline Temperature & 2,12 & 0.248 & 0.784 \\
\hline $\mathrm{C}$ and $\mathrm{N}$ treatments & 3,12 & 4.486 & $0.025^{*}$ \\
\hline Temperature $\times$ Treatments & 6,12 & 3.466 & $0.032^{*}$ \\
\hline \multicolumn{4}{|l|}{ Ph-ERK } \\
\hline Temperature & 2,12 & 28.419 & $<0.001^{*}$ \\
\hline $\mathrm{C}$ and $\mathrm{N}$ treatments & 3,12 & 0.376 & 0.772 \\
\hline Temperature $\times$ Treatments & 6,12 & 2.706 & 0.067 \\
\hline
\end{tabular}

ture $+4^{\circ} \mathrm{C}$ (Holm-Sidak, all $\left.\mathrm{p}<0.05\right)$. In contrast, in both LN treatments, irrespective of the $\mathrm{pCO}_{2}$, a significant increase in JNK phosphorylation occurred after $24 \mathrm{~h}$ at increased temperature, which persisted or even slightly increased at $72 \mathrm{~h}$ (Holm-Sidak, all p $<0.05)$. In addition, a small but significant increase in JNK phosphorylation was found in HCHN after $72 \mathrm{~h}$
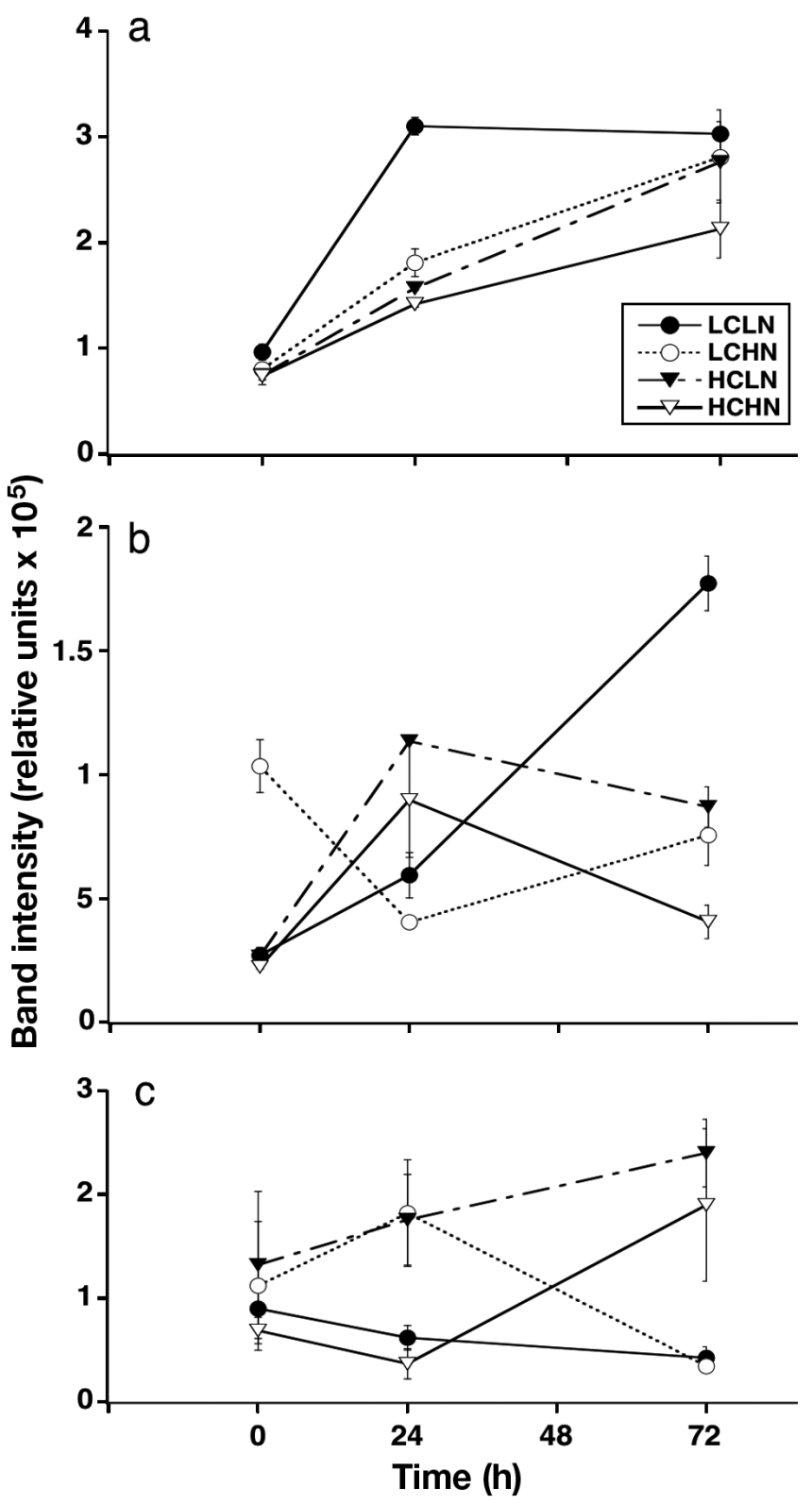

Fig. 5. Expression levels of the phosphorylated p38-like proteins in (a) Ulva rigida, (b) Ellisolandia elongata and (c) Cystoseira tamariscifolia exposed to different carbon and nitrogen treatments (LCLN: low C, low N; LCHN: low C, high $\mathrm{N}_{\text {; }}$ HCLN: high $\mathrm{C}$, low $\mathrm{N}_{\text {; }} \mathrm{HCHN}$ : high $\mathrm{C}$, high N). Algae were sampled at Time 0 (start of the experiment), and 24 and $72 \mathrm{~h}$ after a $4^{\circ} \mathrm{C}$ temperature increase. Data are mean $\left( \pm \mathrm{SE}_{\mathrm{n}} \mathrm{n}=3\right)$ band intensity measured on Western blots

(Holm-Sidak, all $\mathrm{p}<0.05$ ). In the case of $C$. tamariscifolia, the response to higher temperature occurred through an increase in the phosphorylation level of the $42 \mathrm{kDa}$ JNK-like protein in all treatments (Fig. 4c, Table 2; Holm-Sidak, all $\mathrm{p}<0.05$ ). As shown, the response was faster and slightly more pronounced in LN than in HN conditions. Thus, different responses 


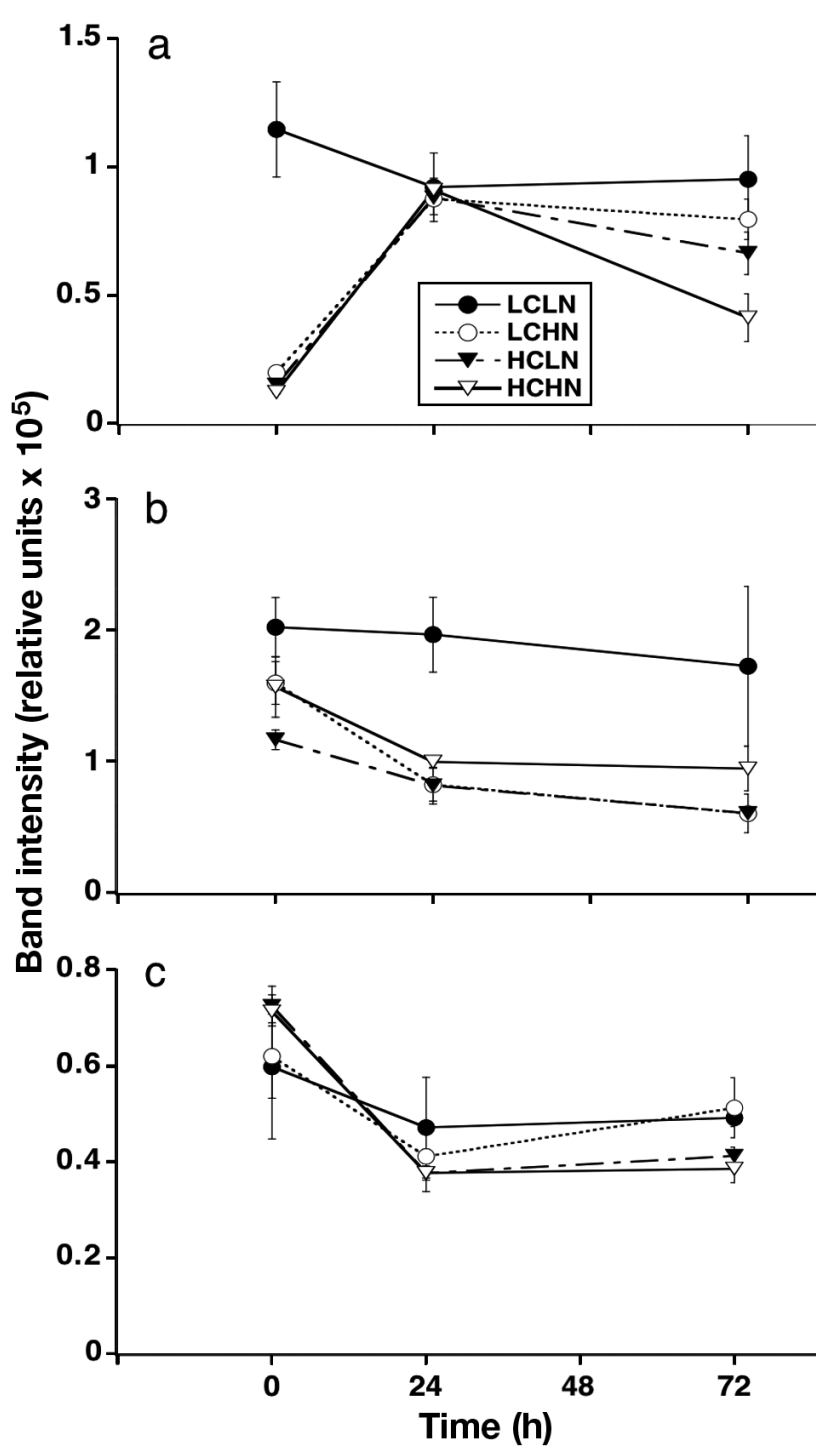

Fig. 6. Expression levels of the phosphorylated ERK-like proteins in (a) Ulva rigida, (b) Ellisolandia elongata and (c) Cystoseira tamariscifolia exposed to different carbon and nitrogen treatments (LCLN: low $\mathrm{C}$, low $\mathrm{N}_{\text {; }} \mathrm{LCHN}$ : low $\mathrm{C}$,

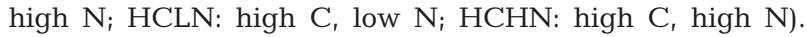
Algae were sampled at Time 0 (start of the experiment), and 24 and $72 \mathrm{~h}$ after a $4^{\circ} \mathrm{C}$ temperature increase. Data are mean $( \pm \mathrm{SE} ; \mathrm{n}=3)$ band intensity measured on Western blots

were detected for the 3 species: in $U$. rigida, new phosphorylation of JNK occurred only in $\mathrm{HC}$, and this phosphorylation was transient. However, in E. elongata, new phosphorylation was detected in LN, while in C. tamariscifolia, it occurred in all treatments.

A second MAPK-like protein of $40 \mathrm{kDa}$ was detected (Fig. 5) by using a phospho-p38 mammalian antibody. Phosphorylation of this kinase in $U$. rigida was very mild, and similar, in all $\mathrm{C}$ and $\mathrm{N}$ treatments in the basal state before temperature increase. A significant increase occurred after $24 \mathrm{~h}$ at the new temperature in all treatments (Holm-Sidak, all p < 0.05), being more pronounced in LCLN. The intensity of phosphorylation continued to increase during the next $48 \mathrm{~h}$ in all treatments except in LCLN, where maximal phosphorylation was achieved after $24 \mathrm{~h}$. Even though phosphorylation increased in all treatments at temperature $+4^{\circ} \mathrm{C}$, the final degree of phosphorylation was significantly lower in HCHN than in the rest of the treatments (Table 2; Holm-Sidak, all $\mathrm{p}<0.05)$. A very different behaviour was expressed in E. elongata (Fig. 5b). Initial phosphorylation before the temperature increase was detected mainly in LCHN, which dropped by $50 \%$ after $24 \mathrm{~h}$ at temperature $+4^{\circ} \mathrm{C}$, and partially recovering after $72 \mathrm{~h}$. In contrast, in both HC treatments there was a significant and transient rise in p38 phosphorylation at 24 $\mathrm{h}$, partially dropping at $72 \mathrm{~h}$ (Holm-Sidak, all $\mathrm{p}<$ 0.05). In the case of LCLN, p38 phosphorylation rose linearly during the $72 \mathrm{~h}$ after temperature increase, reaching the highest level of phosphorylation detected in this seaweed. Thus, the highest activation occurred in LCLN, while the lowest was found in HCHN (Fig. 5b). In C. tamariscifolia, within $72 \mathrm{~h}$ after the rise in temperature no significant differences in the degree of phosphorylation of the $40 \mathrm{kDa}$ p38-like MAPK were detected (Fig. 5c; Holm-Sidak, all $\mathrm{p}>0.05)$. Phosphorylation was higher in $\mathrm{HC}$ than in LC after $72 \mathrm{~h}$ and in addition, nitrogen concentration did not introduce significant differences in phosphorylation (Table 2; Holm-Sidak, all p > 0.05). Increased temperature induced an increase in the phosphorylation in $U$. rigida in all treatments, while in C. tamariscifolia no significant differences occurred within 72 h; in E. elongata, fast activation was found in $\mathrm{HC}$ ( $24 \mathrm{~h}$ ) but long-lasting activation occurred only in LCLN.

Finally, an ERK-like MAPK was detected in all species (Fig. 6). In U. rigida (Fig. 6a), this protein was mainly phosphorylated in LCLN before the temperature increase. At $24 \mathrm{~h}$ after the temperature increase, a sharp increase in the phosphorylation state was detected in $\mathrm{HC}$ and in LCHN, while a small decrease occurred in LCLN (Holm-Sidak, all p < 0.05), leading to similar phosphorylation of this $44 \mathrm{kDa}$ protein in all treatments. After $72 \mathrm{~h}$, phosphorylation in LCLN stabilized at values similar to $24 \mathrm{~h}$; however, in the rest of the treatments, a significant drop in the phosphorylation level was found (Holm-Sidak, all $\mathrm{p}<0.05$ ), and was strongest in HC. Nevertheless, phosphorylation was higher after $72 \mathrm{~h}$ at temperature $+4^{\circ} \mathrm{C}$ in all cases, except in LCLN, where a small decrease was found. ERK-like phosphorylation in $E$. 
elongata (Fig. 6b) revealed that the highest phosphorylation in this species at Time 0 also occurred in LCLN. Results show that a partial deactivation of ERK occurred during the $72 \mathrm{~h}$ after the rise in temperature in HN (Fig. 6b; Holm-Sidak, all p < 0.05). Finally, ERK phosphorylation dropped in C. tamariscifolia in all cases during the first $24 \mathrm{~h}$ except in LCLN (Fig. 6c; Holm-Sidak, all $\mathrm{p}<0.05$ ), remaining low during the rest of the cultivation period. Thus, ERK was activated only in U. rigida after temperature was increased (except in LCLN), while in the rest of the species, no increase in phosphorylation was detected during the 24 to $72 \mathrm{~h}$ at temperature $+4^{\circ} \mathrm{C}$.

\section{DISCUSSION}

Macroalgal species respond to elevated $\mathrm{CO}_{2}$ levels in different ways, and so far, no general pattern has been described. Israel et al. (1999) reported a decrease in growth rate caused by elevated $\mathrm{CO}_{2}$ in some red algae, and similar effects as well as decreased net photosynthesis or even death of some algae have also been reported (Israel \& Hophy 2002, Aline et al. 2006, Martin \& Gattuso 2009). However, a more recent study reported that growth rates of 13 species of chlorophytes, rhodophytes and phaeophytes cultivated in normal seawater were comparable to their growth in $\mathrm{CO}_{2}$-enriched seawater (Israel \& Hophy 2002), most probably due to the presence of $\mathrm{CO}_{2}$-concentrating mechanisms.

In the current study, observed response of the MAPK-like proteins varied depending on the species of macroalgae and on the growth conditions, e.g. low and high $\mathrm{C}$, low and high $\mathrm{N}$, and low and high temperature. Previous findings of our group have demonstrated the existence and activation of p38like and JNK-like MAPK cascades in both microalgae (Jiménez et al. 2004, García-Gómez et al. 2012) and macroalgae (Parages et al. 2012, 2013, 2014) in response to stress. These protein kinases play a crucial role in early response and acclimation of algae to severe environments (i.e. intertidal systems, Parages et al. 2014), and a decrease in the phosphorylation of those kinases leads to reduced survival in algae (Jiménez et al. 2004, Parages 2012). In addition, presence of ERK-like MAPK was detected in all species. Active cell division occurs only when ERK is phosphorylated, and its dephosphorylation leads to cell division arrest, followed by cell death (Jiménez et al. 2007).

Intertidal communities of macroalgae are permanently exposed to a harsh and highly fluctuating environment, in which they have to be very well adapted to the severe conditions. All 3 species used in this research showed phosphorylation of MAPKlike proteins both before and after the temperature increase, and both in low and high carbon and nitrogen conditions. However, significant differences appeared between the species. No growth data are available for this set of experiments, thus no conclusions about the integrated response of these species can be drawn. In vivo fluorescence data obtained using PAM fluorometry as well as MAPK analysis give us a partial view of the different processes involved in the response of the different species to the stressful conditions tested in this work. According to the fluorescence data (Figs. 1 \& 2), LCLN seemed to be the most stressful physiological condition for Ulva rigida, probably due to $\mathrm{C}$ limitation. Other data obtained during the GAP9 Workshop indicated that physiological fitness of $U$. rigida was highest at $\mathrm{HC}$ and $\mathrm{HN}$ before the temperature increase and that the lowest photoinhibition at elevated temperature $\left(+4^{\circ} \mathrm{C}\right)$ occurred in the HCHN treatment $(\mathrm{F} . \mathrm{L}$. Figueroa et al. unpubl. data); thus, U. rigida is able to benefit from high carbon and high nitrogen availability. Those authors found that photoinhibition at midday was highest in LN, and that in parallel, ETR was lowest under $\mathrm{N}$ limitation (independently of the temperature). HCLN conditions seemed to be responsible for the drop in photosynthesis. In this sense, Gordillo et al. (2001) showed that growth rate increased in $U$. rigida at high $\mathrm{CO}_{2}$, but both photosynthesis and respiration rates were decreased at high $\mathrm{CO}_{2}$.

In the present work, we have shown that JNK-like MAPK in U. rigida was highly phosphorylated in LC before the temperature increase, in agreement with the house-keeping role of this MAPK (as previously shown in other algae by Jiménez et al. 2004, GarcíaGómez et al. 2012 and Parages et al. 2012, and in mammalian cells by Capasso et al. 2001). The rise in temperature introduced a new stress condition in the LCLN-grown thalli, which showed an immediate response driven by p38 phosphorylation (Fig. 5), while both ERK (Fig. 6) and JNK (Fig. 4) phosphorylation decreased at the elevated temperature. A clear difference appeared between HC and LC: in HC, the response to increased temperature was mostly driven by JNK phosphorylation during the first $24 \mathrm{~h}$, followed by p38 phosphorylation during the next $48 \mathrm{~h}$. However, increasing temperature in LC mostly induced phosphorylation of $\mathrm{p} 38$. In addition, activation of ERK at temperature $+4^{\circ} \mathrm{C}$ in all cases except in LCLN suggested that cell division was enhanced by 
temperature in $\mathrm{HC}$ and $\mathrm{HN}$ treatments. As mentioned, in $U$. rigida JNK was already highly activated in LC before the temperature increase, and at elevated temperature, p38 was rapidly activated in LCLN. In parallel, JNK was partially deactivated under those conditions. Jiménez et al. (2004) showed that in the unicellular microalga Dunaliella viridis, phosphorylation of p38-like MAPK after stress extended longer in time than that of JNK, as in the case of $U$.rigida.

It is not easy to establish a direct correlation between fluorescence data and MAPKs involved in the response to stress (i.e. JNK and p38). As shown, both $F_{\mathrm{v}} / F_{\mathrm{m}}$ and ETR returned to initial values after $72 \mathrm{~h}$ at the elevated temperature in nearly all cases, indicating that acclimation to the new conditions was achieved. Previous data have shown that inhibition of JNK phosphorylation in macroalgae under high irradiance or UV stress led to decreased optimal quantum yield and eventually to cell death (Parages 2012, M. L. Parages \& C. Jiménez unpublished data). In addition, García-Gómez et al. (2012) and Parages et al. (2013) have shown that an apparent lack of correlation between fluorescence data and MAPK phosphorylation state may temporarily occur both in microalgae and macroalgae.

The behaviour of MAPK-like proteins in Ellisolandia elongata was different than in $U$. rigida. A rapid and very significant increase of p38, and to a lesser extent of JNK, phosphorylation during the first $24 \mathrm{~h}$ at elevated temperature was found with the exception of LCHN, indicating that the stressresponse mechanism had to be activated in E. elongata to acclimate to the new growth conditions. The finding that ERK phosphorylation decreased at elevated temperature indicates that stressful conditions may partially inhibit cell division and algal growth, in agreement with Jiménez et al. (2004). In this species, both p38 and JNK activation seemed to be responsible for triggering the stress-response system in LCLN after the temperature increase, while a transient activation ( $24 \mathrm{~h}$ ) of p38 was detected in HC. Another difference compared to $U$. rigida is that activation of JNK was not transient but instead persisted in time. This behaviour in HC thalli under temperature stress was similar to that already described in Dunaliella tertiolecta after exposure to UVR (García-Gómez et al. 2012), where a transient increase (24 h) of p38 phosphorylation was detected. In E. elongata, ERK phosphorylation decreased in all $\mathrm{C}$ and $\mathrm{N}$ combinations after exposure to elevated temperature $\left(+4^{\circ} \mathrm{C}\right)$, which could indicate that cell division and algal growth decrease compared to initial conditions at ambient temperature (Jiménez et al. 2007, GarcíaGómez et al. 2012). In the case of $U$. rigida, ERK phosphorylation was higher at temperature $+4^{\circ} \mathrm{C}$ than at ambient temperature (except in LCLN), which may indicate that this species benefits from increased temperature if $\mathrm{C}$ and $\mathrm{N}$ are not limiting. All these data indicate that $E$. elongata might be close to its upper temperature limit under the conditions tested here. Several authors (e.g. Somero 2002, Hughes et al. 2003) proposed that many marine organisms already live close to their thermal tolerances, and thus increases in temperature can negatively impact their performance and survival.

One of the effects of global change is the evolution of macroalgal communities in an acidified ocean. Calcareous species appear to be amongst the most sensitive photoautotrophs, as they have a skeletal mineralogy that dissolves easily at predicted levels of calcium carbonate saturation (Gao et al. 1993, Martin \& Gattuso 2009). At a mean $\mathrm{pH}$ of 7.8 , predictions indicate a $25 \%$ loss in the biodiversity of calcareous algae and a major reduction in cover of all erect articulated genera (the calcitic Jania rubens, Corallina officinalis, C. elongata, Amphiroa rigida, A. criptarthrodia and the aragonitic Halimeda tuna; Porzio et al. 2011). Gao \& Zheng (2010) showed that growth of Corallina sessilis was inhibited at high $\mathrm{CO}_{2}$ levels, decreasing the net photosynthetic rate by $29.3 \%$ and the calcification rate by $25.6 \%$ compared to a low $\mathrm{CO}_{2}$ /high $\mathrm{pH}$ treatment. In addition, growth, photosynthesis and calcification rates were further inhibited in the presence of UVR as compared to PAR alone. Connell \& Russell (2010) reported that increased $\mathrm{CO}_{2}$ levels (550 ppm) had no effect on the cover of turf algae at ambient temperature $\left(17^{\circ} \mathrm{C}\right)$ but that turf cover increased considerably when increased $\mathrm{CO}_{2}$ levels were combined with elevated temperatures. Under these conditions, corallinaceans were unable to compete for the space. Previously, Russell et al. (2009) concluded that the combination of both elevated $\mathrm{CO}_{2}$ and nutrient concentrations had negative effects on the biomass of coralline crusts. Martin \& Gattuso (2009) investigated the synergistic effects of high $\mathrm{CO}_{2}$ and increased temperature on Lithophyllum cabiochae, concluding that algal necrosis appeared at elevated temperature, and initially at $700 \mathrm{ppm}$ (60\% of the thallus surface) and later at $400 \mathrm{ppm} \mathrm{CO}_{2}(30 \%)$. Algal death was observed only at the highest temperature and was 2 to 3 times higher at high $\mathrm{CO}_{2}$.

In the case of Cystoseira tamariscifolia, a rapid response to increasing temperature occurred in some cases without further activation of the stress- 
response mechanism mediated by MAPKs. Our results demonstrated that the level of active (phosphorylated) p38- and JNK-like proteins in this species was altered when a change in temperature occurred $\left(+4^{\circ} \mathrm{C}\right)$, but activation of MAPKs varied depending on $\mathrm{C}$ and $\mathrm{N}$ availability. Results show that JNK phosphorylation was mainly responsible for activation of the stress response in LN, with a fast and continuous increase of phosphorylation during $72 \mathrm{~h}$ after temperature increase. However, in HN this increase of JNK phosphorylation only started after $24 \mathrm{~h}$. In general, it may be said that the response to stress in LN was principally mediated by JNK activation, and that the response in HN occurred mainly through p38 activation. In all cases, a significant drop in ERK phosphorylation occurred, which might indicate that the new temperature was above the optimal for growth of C. tamariscifolia. Connell et al. (2008) concluded that turf expansion at high $\mathrm{CO}_{2}$ and elevated temperature would not just negatively affect growth of calcareous algae, but would also inhibit kelp recruitment. $C$. tamariscifolia is well acclimated to increased solar irradiance, presenting high photosynthetic yields and accumulation and release of antioxidant substances (i.e. polyphenolic compounds; Abdala-Díaz et al. 2006); however, no clear information on responses to the combination of elevated $\mathrm{CO}_{2}$ and temperature is available.

In Arctic macroalgae, we have found differential behaviour in 2 species of phaeophytes (Parages et al. 2013). The endemic Laminaria solidungula presented phosphorylated JNK- and p38-like proteins at steady state conditions (PAR at $2^{\circ} \mathrm{C}$ ), that increased after exposure to UVR and increased temperature (from 2 to $7^{\circ} \mathrm{C}$ ). This increase in phosphorylation was more pronounced in the case of JNK than in p38 under both stressors. In turn, Saccharina latissima, a non-endemic species, showed a decrease in both JNK and p38 phosphorylation after temperature increase at any radiation condition, while UVR, as expected, also induced an increase in phosphorylation. In this species, p38 was more activated than JNK. L. solidungula is an endemic Arctic species, and increased temperature to $7^{\circ} \mathrm{C}$ was close to its upper tolerance limit; in the case of $S$. latissima, $2^{\circ} \mathrm{C}$ was close to its lower tolerance limit. This differential behaviour of p38 and JNK phosphorylation in response to environmental stress also occurs in intertidal macroalgae from southern Spain; Parages et al. (2014) described that in several species (e.g. Chaetomorpha aerea and Dilophus spiralis) JNK was primarily activated at low tide, while in Jania rubens p38 was the main MAPK activated during emersion. High irradiance also induced a significant increase in MAPK phosphorylation in several species (including U. rigida, Dictyota dichotoma and Corallina elongata), and in all cases, p38 responded faster than JNK. In the case of the microalgae Dunaliella viridis (Jiménez et al. 2004) and Dunaliella tertiolecta (García-Gómez et al. 2012), p38 was rapidly activated after increased salinity in the former species and increased UVR in the latter species.

In conclusion, our study demonstrates that MAPKlike proteins are involved in the response of intertidal macroalgae to environmental stress imposed by ocean acidification, nitrogen limitation and elevated temperature, and that phosphorylation/dephosphorylation of several kinases (p38-like, JNK-like and ERK-like MAPKs) occurs under these conditions. The phosphorylation response of MAPKs differed between kinases and varied between macroalgal species. Activation of p38 is crucial for acclimation of $U$. rigida to the new temperature under $\mathrm{C}$ limitation; however, JNK played the role of activating the stress response mechanisms in HC. Similarly, p38 was activated in LCLN, but JNK phosphorylation also increased during the first $24 \mathrm{~h}$. Conversely to U. rigi$d a$, p38 was primarily activated in E. elongata in $\mathrm{HC}$. Finally, in C. tamariscifolia JNK was mainly activated in LN during the first $24 \mathrm{~h}$. In addition, $U$. rigida was the only species in which ERK phosphorylation increased at temperature $+4^{\circ} \mathrm{C}$, indicating active cell division. As stated before, U. rigida probably benefitted from elevated carbon and nitrogen levels at ambient temperatures, such that increasing temperature was not as stressful as nutrient limitation. The new temperature was likely above optimal for growth of both E. elongata and C. tamariscifolia. Our data support the hypotheses of Pergent (1991) and Porzio et al. (2011) that in future climate scenarios, Ulvales might dominate Mediterranean intertidal systems in human-disturbed areas where nutrients are not limiting and in $\mathrm{CO}_{2}$-enriched environments with no nutrient limitation.

Acknowledgements. C.J. and M.L.P. were supported by the Ministry of Science and Innovation of Spain (Grant No. CTM2011-24007). We are grateful for financial contributions to the GAP 9 workshop 'Influence of the pulsed-supply of nitrogen on primary productivity in phytoplankton and marine macrophytes: an experimental approach' made by Walz GmbH (facilitating the use of several PAM fluorometers), Redox, University of Málaga, Ministry of Economy and Competitivity of the Spanish Government (Acción Complementaria CTM2011-15659-E), the Project Interacid (RNM5750) of the Junta de Andalucía and Spanish Institute of Oceanography. 


\section{LITERATURE CITED}

Abdala-Díaz RT, Cabello-Pasini A, Pérez-Rodríguez E, Conde Álvarez RM, Figueroa FL (2006) Daily and seasonal variations of optimum quantum yield and phenolic compounds in Cystoseira tamariscifolia (Phaeophyta). Mar Biol 148:459-465

> Aline T, Atkinson MJ, Langdon C (2006) Effects of elevated $\mathrm{pCO}_{2}$ on epilithic and endolithic metabolism of reef carbonates. Glob Change Biol 12:2200-2208

Bischof K, Gómez I, Molis M, Hanelt D and others (2006) Ultraviolet radiation shapes seaweed communities. Rev Environ Sci Biotechnol 5:141-166

Caldeira K, Wickett ME (2003) Anthropogenic carbon and ocean $\mathrm{pH}$. Nature 425:365

Capasso JM, Rivard CJ, Berl T (2001) The expression of the $\gamma$ subunit of Na-K-ATPase is regulated by osmolality via C-terminal Jun kinase and phosphatidylinositol 3-kinasedependent mechanisms. Proc Natl Acad Sci USA 98: 13414-13419

Connell SD, Russell BD (2010) The direct effects of increasing $\mathrm{CO}_{2}$ and temperature on non-calcifying organisms: increasing the potential for phase shifts in kelp forests. Proc R Soc Lond B Biol Sci 277:1409-1415

Connell SD, Russell BD, Turner DJ, Shepherd SA and others (2008) Recovering a lost baseline: missing kelp forests from a metropolitan coast. Mar Ecol Prog Ser 360:63-72

> Davison IR, Pearson GA (1996) Stress tolerance in intertidal seaweeds. J Phycol 32:197-211

Dring MJ (1982) The biology of marine plants. Cambridge University Press, Cambridge

Feely RA, Sabine CL, Lee K, Berelson W, Kleypas J, Fabry VJ, Millero FJ (2004) Impact of anthropogenic $\mathrm{CO}_{2}$ on the $\mathrm{CaCO}_{3}$ system in the oceans. Science 305:362-366

Figueroa FL, Conde-Álvarez R, Gómez I (2003) Relations between electron transport rates determined by pulse amplitude modulated chlorophyll fluorescence and oxygen evolution in macroalgae under different light conditions. Photosynth Res 75:259-275

Figueroa FL, Israel A, Neori A, Martínez B and others (2009) Effects of nutrient supply on photosynthesis and pigmentation in Ulva lactuca (Chlorophyta): responses to shortterm stress. Aquat Biol 7:173-183

Gao K, Xu J (2010) Ecological and physiological responses of macroalgae to solar and UV radiation. In: Israel A, Einav R, Seckbach J (eds) Seaweeds and their role in globally changing environments. Springer, Dordrecht, p 183-198

Gao K, Zheng Y (2010) Combined effects of ocean acidification and solar UV radiation on photosynthesis, growth, pigmentation and calcification of the coralline alga Corallina sessilis (Rhodophyta). Glob Change Biol 16: 2388-2398

Gao K, Aruga Y, Asada K, Ishihara T, Akano T, Kiyohara M (1993) Calcification in the articulated coralline alga Corallina pilulifera, with special reference to the effect of elevated $\mathrm{CO}_{2}$ concentration. Mar Biol 117:129-132

García-Gómez C, Parages ML, Jiménez C, Palma A, Mata MT, Segovia M (2012) Cell survival after UV radiation stress in the unicellular chlorophyte Dunaliella tertiolecta is mediated by DNA repair and MAPK phosphorylation. J Exp Bot 63:5259-5274

Genty B, Briantais JM, Baker NR (1989) The relationship between the quantum yield of photosynthetic electron transport and quenching of chlorophyll fluorescence.
Biochim Biophys Acta 990:87-92

> Gévaert F, Créach A, Davoult D, Migné A and others (2003) Laminaria saccharina photosynthesis measured in situ: photoinhibition and xanthophyll cycle during a tidal cycle. Mar Ecol Prog Ser 247:43-50

Gordillo FJL, Niell FX, Figueroa FL (2001) Non-photosynthetic enhancement of growth by high $\mathrm{CO}_{2}$ level in the nitrophilic seaweed Ulva rigida C. Agardh (Chlorophyta). Planta 213:64-70

> Grzymski J, Johnsen G, Sakshug E (1997) The significance of intracellular self-shading on the bio-optical properties of brown, red and green macroalgae. J Phycol 33: 408-414

Häder DP, Figueroa FL (1997) Photoecophysiology of marine macroalgae. Photochem Photobiol 66:1-14

Hind KR, Saunders GW (2013) A molecular phylogenetic study of the tribe Corallineae (Corallinales, Rhodophyta) with an assessment of genus-level taxonomic features and descriptions of novel genera. J Phycol 49:103-114

> Hofmann LC, Straub S, Bischof K (2013) Elevated $\mathrm{CO}_{2}$ levels affect the activity of nitrate reductase and carbonic anhydrase in the calcifying rhodophyte Corallina officinalis. J Exp Bot 64:899-908

Houghton JT, Ding Y, Griggs DJ, Noguer $M$ and others (2001) Climate change 2001: the scientific basis. Contribution of Working Group I to the Third Assessment Report of the Intergovernmental Panel on Climate Change. Cambridge University Press, Cambridge

Hughes TP, Baird AH, Bellwood DR, Card M and others (2003) Climate change, human impacts, and the resilience of coral reefs. Science 301:929-933

Israel A, Hophy M (2002) Growth, photosynthetic properties and Rubisco activities and amounts of marine macroalgae grown under current and elevated seawater $\mathrm{CO}_{2}$ concentrations. Glob Change Biol 8:831-840

Israel A, Katz S, Dubinsky Z, Merrill JE, Friedlander M (1999) Photosynthetic inorganic carbon utilization and growth of Porphyra linearis (Rhodophyta). J Appl Phycol 11:447-453

Jiménez C, Berl T, Rivard CJ, Edelstein CL, Capasso JM (2004) Phosphorylation of MAP kinase-like proteins mediate the response of the halotolerant alga Dunaliella viridis to hypertonic shock. Biochim Biophys Acta 1644: 61-69

> Jiménez C, Cossío BR, Rivard CJ, Berl T, Edelstein CL, Capasso JM (2007) Cell division in the unicellular microalga Dunaliella viridis depends on phosphorylation of extracellular signal-regulated kinases (ERKs). J Exp Bot 58:1001-1011

Karleskint G, Turner R, Small J (2010) Introduction to marine biology. Brooks/Cole, Belmont, CA

Kyriakis JM, Avruch J (2001) Mammalian mitogen-activated protein kinase signal transduction pathways activated by stress and inflammation. Physiol Rev 81:807-869

> Ligterink W (2000) MAP kinases in plant signal transduction: how many, and what for? Results Probl Cell Differ $27: 11-27$

Littler MM, Taylor PR, Littler DS (1983) Algal resistance to herbivory on a Caribbean barrier reef. Coral Reefs 2: 111-118

Lobban CS, Harrinson PG (1994) Seaweed ecology and physiology. Cambridge University Press, Cambridge

Martin S, Gattuso JP (2009) Response of Mediterranean coralline algae to ocean acidification and elevated temperature. Glob Change Biol 15:2089-2100 
Mishra NS, Tuteja R, Tuteja N (2006) Signaling through MAP kinase networks in plants. Arch Biochem Biophys 452:55-68

Ní Longphuirt S, Stengel D, O'Dowd C, McGovern E (2010) Ocean acidification: an emerging threat to our marine environment. Marine Foresight Series no. 6. Marine Institute, Oranmore

> Orr JC, Fabry VJ, Aumont O, Bopp L and others (2005) Anthropogenic ocean acidification over the twenty-first century and its impact on calcifying organisms. Nature 437:681-686

Parages ML (2012) Role of mitogen activated protein kinases (MAPKs) cascades in environmental stress signal transduction in intertidal and Arctic macrophytes. PhD dissertation, University of Málaga

Parages ML, Capasso JM, Meco V, Jiménez C (2012) A novel method for phosphoprotein extraction from macroalgae. Bot Mar 55:261-267

Parages ML, Heinrich S, Wiencke C, Jiménez C (2013) Rapid phosphorylation of MAP kinase-like proteins in two species of Arctic kelps in response to temperature and UV radiation stress. Environ Exp Bot 91:30-37

Parages ML, Capasso JM, Niell FX, Jiménez C (2014) Environmental stress response by cyclic phosphorylation of MAP kinase-like proteins in intertidal macrophytes. J Plant Physiol 171:276-284

Pawson T, Scott JD (1997) Signaling through scaffold, anchoring, and adaptor proteins. Science 278:2075-2080

Pergent G (1991) Les indicateurs écologiques de la qualité

Submitted: December 9, 2013; Accepted: July 24, 2014 du milieu marin en Méditerranée. Oceanis 17:341-350

Porzio L, Buia MC, Hall-Spencer JM (2011) Effects of ocean acidification on macroalgal communities. J Exp Mar Biol Ecol 400:278-287

Ramírez T, Cortés D, Mercado JM, Vargas-Yáñez M, Sebastián M, Liger E (2005) Seasonal dynamics of inorganic nutrients and phytoplankton biomass in the NW Alboran Sea. Estuar Coast Shelf Sci 65:654-670

Ritchie RJ (2006) Consistent sets of spectrophotometric chlorophyll equations for acetone, methanol and ethanol solvents. Photosynth Res 89:27-41

Russell BD, Thompson JI, Falkenberg LJ, Connell SD (2009) Synergistic effects of climate change and local stressors: $\mathrm{CO}_{2}$ and nutrient driven change in subtidal rocky habitats. Glob Change Biol 15:2153-2162

Schreiber U, Schliwa U, Bilger W (1986) Continuous recording of photochemical and non-photochemical chlorophyll fluorescence quenching with a new type of modulation fluorometer. Photosynth Res 10:51-62

Sinha AK, Jaggi M, Raghuram B, Tuteja N (2011) Mitogenactivated protein kinase signaling in plants under abiotic stress. Plant Signal Behav 6:196-203

Somero GN (2002) Thermal physiology and vertical zonation of intertidal animals: optima, limits, and costs of living. Integr Comp Biol 42:780-789

Stengel DB, Conde-Âlvarez R, Connan S, Nitschke U and others (2014) Short-term effects of $\mathrm{CO}_{2}$, nutrients and temperature on three marine macroalgae under solar radiation. Aquat Biol 22:159-176

Proofs received from author(s): September 18, 2014 